\title{
Rapid polarization of Th2 cells during induction of antigen-specific IgE antibodies in vitro
}

\author{
A. ÅKESSON, S. INGVARSSON, K. BRADY*, P. MOYNAGH* and \\ C. A. K. BORREBAECK \\ Department of Immunotechnology, Lund University, Sweden, *Department of Pharmacology, University Collage Dublin, \\ Ireland
}

\begin{abstract}
Summary
Background Type 2 T-helper cells (Th2) are involved in the regulation of the humoral immune response against antigens and allergens and directly affect which isotype will be produced. The mechanism that regulates antigen-specific IgE secretion and immune deviation is still not known.

Objectives To delineate mechanisms behind antigen-specific IgE secretion we have used in vitro immunization and focused on T-cell phenotype and the activation status of the transcription factor $\mathrm{NF} \kappa \mathrm{B}$.

Methods Peripheral blood lymphocytes (PBMC) from seronegative donors were immunized in vitro with a peptide consisting of both a T-cell and a B-cell epitope.

Results Antigen-specific IgE antibodies could be detected after a primary immunization, during which T-helper cells secreted type 2 cytokines. Specific IgE was also detected in the secondary immunization, but due to a rapid polarization from Th2 to Th1 phenotype, exogenous IL-4 was required for the specific IgE secretion. Analysis of $\mathrm{NF}_{\kappa} \mathrm{B}$ activation in $\mathrm{B}$ and $\mathrm{T}$ cells during primary and secondary immunization showed that $\mathrm{NF}_{\kappa} \mathrm{B}$ could be detected in both $\mathrm{B}$ and $\mathrm{T}$ cells during primary immunization, but was dependent on exogenous IL-4 in the secondary immunization.

Conclusion This is the first evidence of antigen-specific IgE induction in vitro using naive $\mathrm{B}$ cells, demonstrating the involvement of T-helper cell phenotype and NF $\kappa$ B and demonstrates the usefulness of in vitro cultures to study the effect of antigens on human immunocytes.
\end{abstract}

Keywords: Antigen specific, $\mathrm{IgE}$, in vitro, $\mathrm{NF}_{\kappa} \mathrm{B}$, immune deviation

Clinical and Experimental Allergy, Vol. 30, pp. 1298-1306. Submitted 27 August 1999; revised 24 January 2000; accepted 24 February 2000.

\section{Introduction}

The specific immune response to an antigen is largely dependent on activation of T-helper cells that are able to secrete necessary cytokines [1]. The balance between humoral and cellular immunity is orchestrated by cytokines derived from $\mathrm{CD} 4+\mathrm{T}$ cells $(\mathrm{Th})$, which have been further subdivided into Th1 and Th2 cells [2,3]. Th1 cells particular secrete $\mathrm{IFN} \gamma$ and $\mathrm{TNF} \alpha / \beta$, which promote inflammatory cellular immunity and protect against, e.g. intracellular

Correspondence: C. A. K. Borrebaeck, Department of Immuno-technology, Lund University, Box 7031, S-220 07 Lund, Sweden.

1298 microorganisms and cancer. Th2 cells, with a lymphokine production skewed towards IL-4 and IL-13, are involved in humoral immunity and the elimination of extracellular pathogens and also in reducing the risk of Th1 cell-mediated autoimmunity [1]. Atopic allergy to normally harmless proteins is correlated to the development of polarized Th2 with high production of type-2 lymphokines, resulting in antigen-specific IgE secretion. The immune deviation [4] seen in the neonatal immune response of nonatopics is biased towards Th2 responses, which shifts towards Th1 during the first year of life, while atopic children retain their Th2 response [4]. The mechanisms involved in the development of polarized $\mathrm{T}$ helper cells, in particular Th2 cells,

(C) 2000 Blackwell Science Ltd 
Table 1. Peptides used in the in vitro immunization and the antigen-specific IgE ELISA

\begin{tabular}{lll}
\hline Peptide & \multicolumn{1}{c}{ Sequence } & \multicolumn{1}{c}{ Antigen } \\
\hline pTT & QYIKANSKTEL & Tetanus toxoid \\
pV3 & RKSIRIQRGPGRAFV & HIV-1 gp(aa.304-318) \\
pTT-pV3 & QYIKANSKTELRKSIRIQRGPGRAFV & Heterotope of pTT and pV3 \\
pB1 & QLNQSVEINCTRPNNNTRKSIRIQRGPGR & HIV-1 gp 120 \\
& AFVTIGKIGNMRQAHCNISRAKWNNTLK & (aa.294-473, pV3 underlined) \\
& QIDSKLREQFGNNKTIIFKQSSGGDPEIVT & \\
& HSFNCGGEFFYNSTQLFNSTWFNSTWS & \\
& TKGSNNTEGSDTITLPCRIKQIINMWQEV & \\
& GKAMYAPPISGQIRCSSNITGLLLTRDGG & \\
& NSNNESE & \\
\hline
\end{tabular}

as well as of the subsequent antigen-specific IgE secretion need further elucidation and prompted us to investigate these questions using an in vitro approach.

In the present study we used the in vitro immunization system, initially designed to induce antigen-specific isotype switch from $\mu$ to $\gamma$ [5], to also study the induction of specific $\operatorname{IgE}$ secretion. The switching to $\epsilon$ isotype is dependent on lymphokines as well as receptor-mediated signals and it has recently been shown that ligation of CD40 by CD40L, in the presence of soluble IL-4, leads to activation of the transcription factor $\mathrm{NF}_{\kappa} \mathrm{B}$. This factor binds to the $\epsilon$-promoter inducing transcription of the unrearranged constant region gene [6-9]. This transcription facilitates recombination of the variable-region gene $5^{\prime}$ of the expressed IgE constant-region, which will ultimately lead to expression of mature $\mathrm{IgE}$ antibodies. CD40 is thus a central player in regulating $\mathrm{IgE}$ production. The importance of $\mathrm{NF}_{\kappa} \mathrm{B}$ in mediating the effects of CD40 ligation is emphasized by a study, which shows that $\mathrm{NF}_{\kappa} \mathrm{B}$ knockout mice have defects in isotype switching [10]. In addition to its direct role in $\mathrm{B}$ cells, $\mathrm{NF} \kappa \mathrm{B}$ may also have an indirect influence on isotype switching by its effects in T cells [11]. The basis of the present in vitro immunization system is a cognate interaction between $\mathrm{T}$ and $\mathrm{B}$ cells, supported by the use of a heterotope peptide containing a T-helper cell recall epitope and the specific B-cell antigen epitope. The specific B-cell response is driven by antigen activated $\mathrm{T}$ cells and recognition of the B-cell epitope by surface immunoglobulin [12]. We have studied the antigen-specific induction of $\mathrm{IgE}$, using a similar approach, including phenotypic analysis of Th cells during both the primary and secondary in vitro immunization [13]. The activation status of $\mathrm{NF}_{\kappa} \mathrm{B}$ in both T cells and B cells was also probed after different stimulation periods to correlate the activation of $\mathrm{NF} \kappa \mathrm{B}$ with progression of T-cell differentiation and isotype switching.

\section{Materials and methods}

\section{Antibodies, antigens and cytokines}

FITC-labelled anti-CD19, anti-CD14 and anti-CD16 antibodies and the R-phycoerythrin (RPE)-labelled anti-CD3 antibody were obtained from Dako A/S (Glostrup, Denmark). Anti-CD3 FITC was purchased from Becton Dickinson Inc. (San Jose, CA, USA). Anti-CD4 tricolour (TC), was purchased from Caltag (San Francisco, CA, USA). Anti-IL-4-RPE and anti-IFN $\gamma$-RPE were purchased from Pharmingen (San Diego, CA, USA). The S2C6 antiCD40 mAb was a generous gift from Dr Staffan Paulie (Stockholm University, Sweden). Peptide antigens pTT, pV3 and pTT-pV3 were kindly provided by Dr Elias Krambovitis (Institute of Molecular Biology and Biotechnology, Greece). The peptides are shown in Table 1. pB1, a recombinant protein containing most of the C-terminal part of the gp120 (HIV-1) was a generous gift from Repligen Inc. Tetanus toxoid (TT) was purchased from the Swedish Institute for Infectious Disease Control (Stockholm, Sweden). IL-4 was obtained from Genzyme (Cambridge, MA, USA).

\section{Cells and medium}

Buffy coats were obtained from healthy, HIV-1 seronegative donors from the University Hospital Blood Bank (Lund, Sweden). All sera were initially tested in ELISA for antibodies against TT. Peripheral blood mononuclear cells (PBMC) from TT-positive donors were isolated as described previously [13]. Briefly, PBMC were separated from red blood cells on Ficoll-Paque (Pharmacia, Uppsala, Sweden) by density centrifugation. The isolated PBMC were incubated in RPMI 1640, containing $2 \%$ human serum, together with freshly prepared $0.175 \mathrm{~mm}$ L-leucyl- 
L-leucine methyl esterhydrobromide (LLOMe) (Bachem Feinchemikalien AG, Budendorf, Switzerland), for $15 \mathrm{~min}$ at room temperature and then washed three times. After resuspension in medium, containing $10 \%$ human serum, the cells were incubated for $2 \mathrm{~h}$ at $37^{\circ} \mathrm{C}$ to increase the viability of the cell preparation.

RPMI 1640, supplemented with $4 \mathrm{~mm}$ L-glutamine, nonessential amino acids, $50 \mu \mathrm{g} / \mathrm{mL}$ gentamycin (Biological Industries, Haemek, Israel), 10\% heat inactivated human serum (University Hospital Bloodbank, Lund, Sweden) or fetal calf serum (Gibco, Grand Island, NY, USA) was used in all cell cultures unless otherwise stated.

\section{Primary in vitro immunization}

$3 \times 10^{6}$ LLOMe-treated cells were cultured for 7 days in medium containing $10 \%$ human serum, $50 \mu \mathrm{M} 2$-mercaptoethanol, $40 \mathrm{ng}$ IL-2/mL, $25 \%$ T-cell replacing factor (TRF) [5-13]. The cells were immunized with $7 \mathrm{~nm}$ pTT-pV3 peptide.

\section{Generation of activated T-helper cells for the secondary immunization}

$\mathrm{T}$ cells in the LLOMe treated cell population were activated by culturing $1 \times 10^{6}$ cells $/ \mathrm{mL}$ together with $1 \times 10^{6} / \mathrm{mL}$ feeder cells (irradiated autologous PBMC) in tissue culture flasks with $50 \mathrm{~mm} 2$-mercaptoethanol and $10 \mu \mathrm{M}$ pTT for 7 days [12]. At day 3, fresh complete culture medium was added to the cultures.

\section{Secondary in vitro immunization}

Primary immunized cells as well as the activated T cells were harvested and centrifuged through $40 \%$ Ficoll-Paque, at day 7. After one wash, the proportion of $\mathrm{B}$ and $\mathrm{T}$ cell was determined by FACS analysis. $0.5 \times 10^{6} / \mathrm{mL}$ cells from the primary immunization were cocultured together with $0.2 \times 10^{6 /} \mathrm{mL} \mathrm{T}$ cells from the antigen-specific $\mathrm{T}$-cell activation on a monolayer of irradiated CD32-transfected fibroblasts for a secondary immunization period. The cells were cultured for 4 days in medium, supplemented with 5\% human serum, 50 mм 2-mercaptoethanol, 7 nм pTT-pV3 and $0.5 \mu \mathrm{g} / \mathrm{mL}$ anti-CD40 antibody, with and without the supplementation of $100 \mathrm{U}$ IL- $4 / \mathrm{mL}$.

A population of primary and secondary immunized cells were infected with EBV, as described previously [14], and cultured for 10-20 days in presence of irradiated feeder cells in medium containing fetal calf serum. The culture supernatant was then removed and analysed for total as well as antigen-specific human $\mathrm{IgE}$ antibodies.

\section{Intracellular staining}

$\mathrm{T}$ cells were analysed for intracellular cytokines, as described previously [15]. Cells from primary and secondary immunization were treated with $20 \mathrm{ng} / \mathrm{mL}$ PMA and $16 \mu \mathrm{m} / \mathrm{L}$ ionomycin (Sigma-Aldrich Chemie, Germany) over night. Two hours before harvesting the cells, Brefeldin A $5 \mu \mathrm{g} / \mathrm{mL}$ (Sigma-Aldrich Chemie) was added. The cells were washed with PBS supplemented with $1 \%$ BSA and stained with anti-CD3 FITC. The cells were washed twice and fixed with $2 \%$ formaldehyde for $15 \mathrm{~min}$ and then permeabilized after a wash, with $0.5 \%$ Tween for $45 \mathrm{~min}$. The cells were then incubated with anti-IL- 4 or anti-IFN $\gamma$ antibodies. After a 30-min incubation in the dark, the cells were washed and analysed by flow cytometry, using a FACScan (Beckton Dickinson Inc.).

\section{Preparation of nuclear fractions for $N F \kappa B$ analysis}

$\mathrm{B}$ and $\mathrm{T}$ cells from primary and secondary cultures were separated with anti-CD19 and anti-CD3 magnetic beads (Dynal A.S., Oslo, Norway), respectively. After separation, $0.5-1 \times 10^{6}$ cells were centrifuged at $1500 \mathrm{~g}$ for $5 \mathrm{~min}$ and the cells resuspended in $1 \mathrm{~mL}$ hypotonic buffer (10 mM HEPES-NaOH buffer, pH 7.9, containing $1.5 \mathrm{~mm} \mathrm{MgCl}_{2}, 10 \mathrm{~mm} \mathrm{KCl}, 0.5 \mathrm{~mm}$ dithiothreitol and $0.5 \mathrm{~mm}$ PMSF). Cells were pelleted by centrifugation at $14000 \mathrm{~g}$ for $10 \mathrm{~min}$ and then lysed for $10 \mathrm{~min}$ on ice in hypotonic buffer $(20 \mu \mathrm{L})$, containing $0.1 \%$ (v/v) Nonidet P-40. Lysates were centrifuged at $14000 \mathrm{~g}$ for $10 \mathrm{~min}$. The resulting pellets were resuspended in $20 \mathrm{~mm}$ HEPES$\mathrm{NaOH}$ buffer, pH7.9 $(15 \mu \mathrm{L})$, containing $420 \mathrm{~mm} \mathrm{NaCl}$, $1.5 \mathrm{~mm} \mathrm{MgCl}_{2}, 0.2 \mathrm{~mm}$ EDTA, 25\% (w/v) glycerol and $0.5 \mathrm{~mm}$ PMSF and incubated for $15 \mathrm{~min}$ on ice. The nuclear suspensions were then centrifuged at $14000 \mathrm{~g}$ for $10 \mathrm{~min}$ and the supernatants were transferred into $10 \mathrm{~mm}$ HEPES/NaOH buffer, pH7.9 $(75 \mu \mathrm{L})$, containing $50 \mathrm{~mm}$ $\mathrm{KCl}, 0.2 \mathrm{~mm}$ EDTA, 20\% (w/v) glycerol, $0.5 \mathrm{~mm}$ PMSF and $0.5 \mathrm{~mm}$ dithiothreitol. Such samples constituted of nuclear extracts. Protein concentrations of nuclear extracts were determined [16] and the extracts assayed immediately for $\mathrm{NF}_{\kappa} \mathrm{B}$ activity or stored at $-70^{\circ} \mathrm{C}$ until further use. All of the steps in the above procedure were performed at $4{ }^{\circ} \mathrm{C}$, unless otherwise stated.

\section{Electrophoretic mobility shift assay}

Nuclear extracts $(4 \mu \mathrm{g}$ protein) were incubated with 20000 c.p.m. of a 22-bp oligonucleotide containing the $\mathrm{NF} \kappa \mathrm{B}$ consensus sequence, which had been previously labelled with $\left[\gamma^{-}{ }^{32} \mathrm{P}\right] \mathrm{ATP}(10 \mathrm{mCi} / \mathrm{mmol})$ by $\mathrm{T} 4$ polynucleotide kinase [17]. Incubations were performed for $30 \mathrm{~min}$ at room temperature in the presence of $2 \mu \mathrm{g}$ poly 


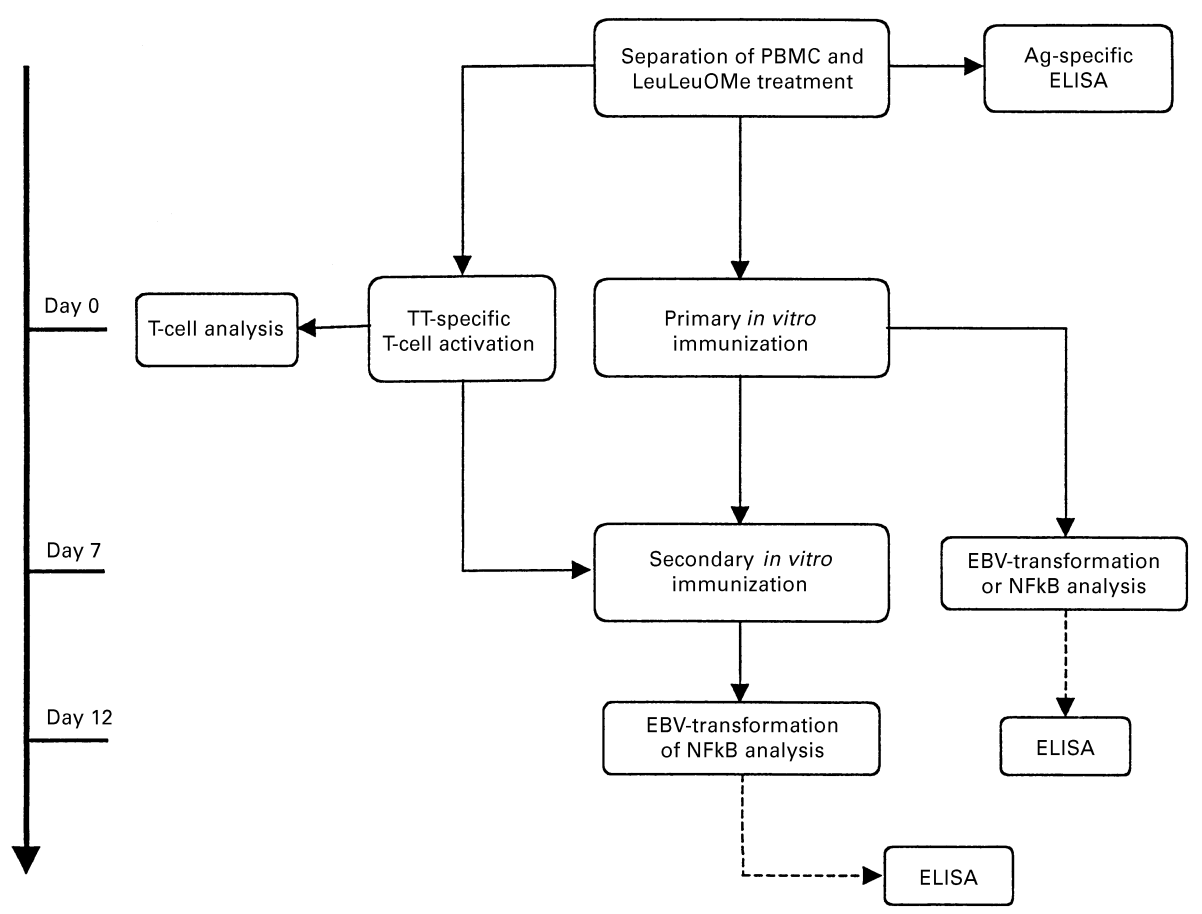

Fig. 1. General outline of the experimental set up utilized to study antigen-specific IgE induction.

(dI-dC) and $10 \mathrm{~mm}$ Tris-HCl buffer, $\mathrm{pH} 7.5$, containing $100 \mathrm{~mm} \mathrm{NaCl}, 1 \mathrm{~mm}$ EDTA, $5 \mathrm{~mm}$ dithiothreitol, 4\% (w/v) glycerol and $0.1 \mathrm{mg} / \mathrm{mL}$ nuclease-free BSA. All incubations were subjected to electrophoresis on $4 \%(\mathrm{w} / \mathrm{v})$ polyacrylamide gels, which were subsequently dried and autoradiographed.

\section{Detection of antigen-specific antibodies with ELISA}

ELISA was performed by coating microtitre plates (Life Technologies, Sweden) with $70 \mathrm{ng} \mathrm{pB} 1 /$ well or $1 \mu \mathrm{g}$ bovine serum albumin/well or $0.05 \mu \mathrm{g}$ rabbit antihuman $\mathrm{IgE} /$ well (Dako A/S Glostrup, Denmark) in sodium carbonate buffer,

Table 2. IgE switch frequency after primary and secondary immunization detected by ELISA

\begin{tabular}{|c|c|c|c|c|c|c|c|c|c|c|c|c|}
\hline \multirow[b]{3}{*}{ Donor } & \multicolumn{4}{|c|}{$\begin{array}{c}\text { Primary } \\
\text { immunization }\end{array}$} & \multicolumn{4}{|c|}{$\begin{array}{c}\text { Secondary } \\
\text { immunization } \\
\text { with IL-4 }\end{array}$} & \multicolumn{4}{|c|}{$\begin{array}{c}\text { Secondary } \\
\text { immunization } \\
\text { without IL-4 }\end{array}$} \\
\hline & \multicolumn{2}{|r|}{$\operatorname{IgE}_{\mathrm{TOT}}$} & \multicolumn{2}{|r|}{$\mathrm{IgE}_{\mathrm{V} 3}$} & \multicolumn{2}{|r|}{$\operatorname{IgE}_{\mathrm{TOT}}$} & \multicolumn{2}{|r|}{$\operatorname{IgE}_{\mathrm{V} 3}$} & \multicolumn{2}{|r|}{$\operatorname{IgE}_{\text {TOT }}$} & \multicolumn{2}{|r|}{$\operatorname{IgE}_{\mathrm{V} 3}$} \\
\hline & $\%$ & No. of wells & $\%$ & No. of wells & $\%$ & No. of wells & $\%$ & No. of wells & $\%$ & No. of wells & $\%$ & No. of wells \\
\hline A & 15 & $58 / 378$ & 3.4 & $13 / 378$ & 3.9 & $4 / 102$ & 0 & $0 / 102$ & 8.3 & $5 / 60$ & 0 & $0 / 60$ \\
\hline B & 1.7 & $12 / 702$ & 1.6 & $11 / 702$ & 43 & $13 / 30$ & 17 & $5 / 30$ & 8.3 & $2 / 24$ & 0 & $0 / 24$ \\
\hline $\mathrm{C}$ & 1.8 & $1 / 54$ & 1.8 & $1 / 54$ & 0 & $0 / 162$ & 0 & $0 / 162$ & 0.6 & $1 / 162$ & 1.2 & $2 / 162$ \\
\hline $\mathrm{D}$ & 6.1 & $10 / 162$ & 3.1 & $5 / 162$ & 4.6 & $5 / 108$ & 1.9 & $2 / 108$ & 0 & $0 / 108$ & 0.1 & $1 / 108$ \\
\hline $\mathrm{E}$ & 12.5 & $27 / 216$ & 3.1 & $5 / 162$ & 3.7 & $4 / 108$ & 0 & $0 / 108$ & 0 & $0 / 108$ & 0 & $0 / 108$ \\
\hline $\mathrm{F}$ & 45 & $73 / 162$ & 0.6 & $1 / 162$ & 2.2 & $3 / 138$ & 0.72 & $1 / 138$ & 0 & $0 / 132$ & 0.75 & $1 / 132$ \\
\hline G & 0 & $0 / 216$ & 0.5 & $1 / 216$ & 3.1 & $5 / 162$ & 0.61 & $1 / 162$ & 1.9 & $3 / 162$ & 0 & $0 / 162$ \\
\hline $\mathrm{H}$ & 3.7 & $10 / 270$ & 1.8 & $5 / 270$ & 6.8 & $13 / 192$ & 1.0 & $2 / 192$ & 0 & $0 / 186$ & 0 & $0 / 186$ \\
\hline
\end{tabular}

Wells containing total and specific IgE antibodies/total number of wells after EBV-transformation given as numbers or percentages. Wells were considered positive if the OD was higher than $\times$ (medium control) $+10 \times \mathrm{SD}$ (medium control). 
Table 3. Reactivity Index (RI)* of in cultures after primary and secondary immunization

\begin{tabular}{lcc} 
& \multicolumn{2}{c}{ RI values $\dagger$} \\
\cline { 2 - 3 } Culture & $>5$ & $>50$ \\
\hline $1^{\circ}$ immunization & $17 / 42$ & $4 / 42$ \\
$2^{\circ}$ immunization + IL-4 & $10 / 12$ & $2 / 12$ \\
$2^{\circ}$ immunization - IL-4 & $2 / 2$ & $0 / 2$
\end{tabular}

*RI was calculated as [OD(peptide specific IgE)-OD(medium control against pB1)]/[OD(BSA)-OD(medium control against BSA)]. Number of antigen-specific wells with a reactivity index (RI) above 5 or 50 were then determined. $†$ Total values from eight individual experiments, using different donors.

$\mathrm{pH} 8.6$, over night at $4{ }^{\circ} \mathrm{C}$. Coated plates were incubated for $1-2 \mathrm{~h}$ in $37^{\circ} \mathrm{C}$ with culture supernatants, diluted three times in PBS $\mathrm{pH} 7$, containinmg $1 \%$ BSA. After washing, the plates were incubated with horse-radish peroxidase (HRP) conjugated rabbit antihuman-IgE $(1: 2000)$ (Dako A/S). Ortho-phenylendiamine (OPD) and hydrogen peroxide (Sigma) was added to each well, as chromogen and substrate, for $15 \mathrm{~min}$. The reaction was stopped by adding $150 \mu \mathrm{L} 1 \mathrm{~m}$ sulphuric acid and the absorbance was measured at $490 \mathrm{~nm}$.

Detection of TT antibodies in sera was performed as described previously [12].

\section{Results}

Induction of antigen-specific IgE by in vitro immunization

A schematic representation of the in vitro immunization system used in this study is outlined in Fig. 1. During the primary stimulation period (day 1-7) B cells receive signals from the antigen, $\mathrm{T}$ cells and exogenously added lymphokines, mainly IL-2 [5], whereas the secondary period (day $8-11)$ provided signals by the antigen, antigen-specifically activated $\mathrm{T}$ cells and CD40 ligation. The result of this stimulation was analysed as the frequency of B cells producing antigen-specific $\operatorname{IgE}$ as well as total $\operatorname{IgE}$ and is shown in Table 2. Antigen-specific IgE antibodies could be detected after both primary and secondary immunization, where the frequency of B cells producing specific antibodies varied between individual donors. The frequency of antigen-specific B cell clones decreased, however, significantly during the secondary stimulation period. This could be reversed when IL-4 was allowed to be present during day 8-11 and then the mean frequency of B cells secreting antigen-specific IgE increased $>10$ times, demonstrating that the switch to an $\epsilon$ isotype was IL-4 dependent in vitro.
The reactivity index (RI) of antigen-specific $\operatorname{IgE}$ antibodies produced by the in vitro immunization was also determined. The RI-values correlate to the amount of $\operatorname{IgE}$ detected in vitro and/or to the antibody affinity of the secreted $\mathrm{IgE}$. The responses were in general very strong with several clones exhibiting RI > 50 (Table 3 ).

\section{Rapid Th1 polarization occurs during the secondary immunization period}

To investigate why the secondary immunization was dependent on exogenously added IL-4 we monitored the Th phenotype during the different stimulation periods. Cells were stained for CD3, fixed and analysed for intracellular cytokines. Thirty to $50 \%$ of T cells from primary immunized cultures (day 7) were positive for intracellular IL-4 but $<5 \%$ of the $\mathrm{CD} 3+\mathrm{T}$ cells produced $\mathrm{IFN} \gamma$ (Fig. 2), indicating that the major phenotype was Th2. The separately generated antigen-specific Th cells had also a Th2 cytokine profile at the initiation of the secondary immunization, which was comparable to the Th cells present during the primary immunization period. Cells were then harvested after the secondary immunization period (day 11) and the cytokine profile was analysed. At this time point, i.e. 11 days after initiation, $>60 \%$ of the Th cells in the cultures were now IFN $\gamma$ positive, whereas less than $2 \%$ were positive for intracellular IL-4 (Fig. 2). This very rapid polarization of cytokine profile occurred over only 4 days and was independently of exogenously added IL-4 to the secondary cultures, i.e. the majority of Th cells was of Th1 phenotype even if $100 \mathrm{U}$ IL-4 had been present. Further attempts were also made to inhibit the Th polarization by modulating some of the other signalling pathways possibly involved in the observed immune deviation during the secondary immunization period. Therefore, the polarization was analysed after, (i) removal of the CD40 signalling and (ii) addition of blocking anti-IL-12 antibodies $(50 \mu \mathrm{g} / \mathrm{mL})$. The polarization from a Th2 to a Th1 phenotype was, however, unaffected by these attempts (data not shown).

\section{Activation of $N F \kappa B$ in $T$ and $B$ cells is dependent on $I L-4$}

To further study the effect of IL-4 on signalling pathways, during the in vitro induction of antigen-specific IgE, we analysed the presence of $\mathrm{NF}_{\kappa} \mathrm{B}$ a transcription factor known to be involved in the inducible transcription of a variety of genes, including the $\epsilon$ isotype and IL-2, a Th1-type cytokine. Nuclear extracts from $\mathrm{T}$ cells which had been subjected to primary immunization showed detectable levels of $\mathrm{NF}_{\kappa} \mathrm{B}$, as determined by electrophoretic mobility shift assay. These levels of $\mathrm{NF} \kappa \mathrm{B}$ were independent of exogenously added IL-4. However, during the secondary in vitro immunization IL-4 promoted an increased activation of $\mathrm{NF}_{\kappa} \mathrm{B}$ in Th cells. 

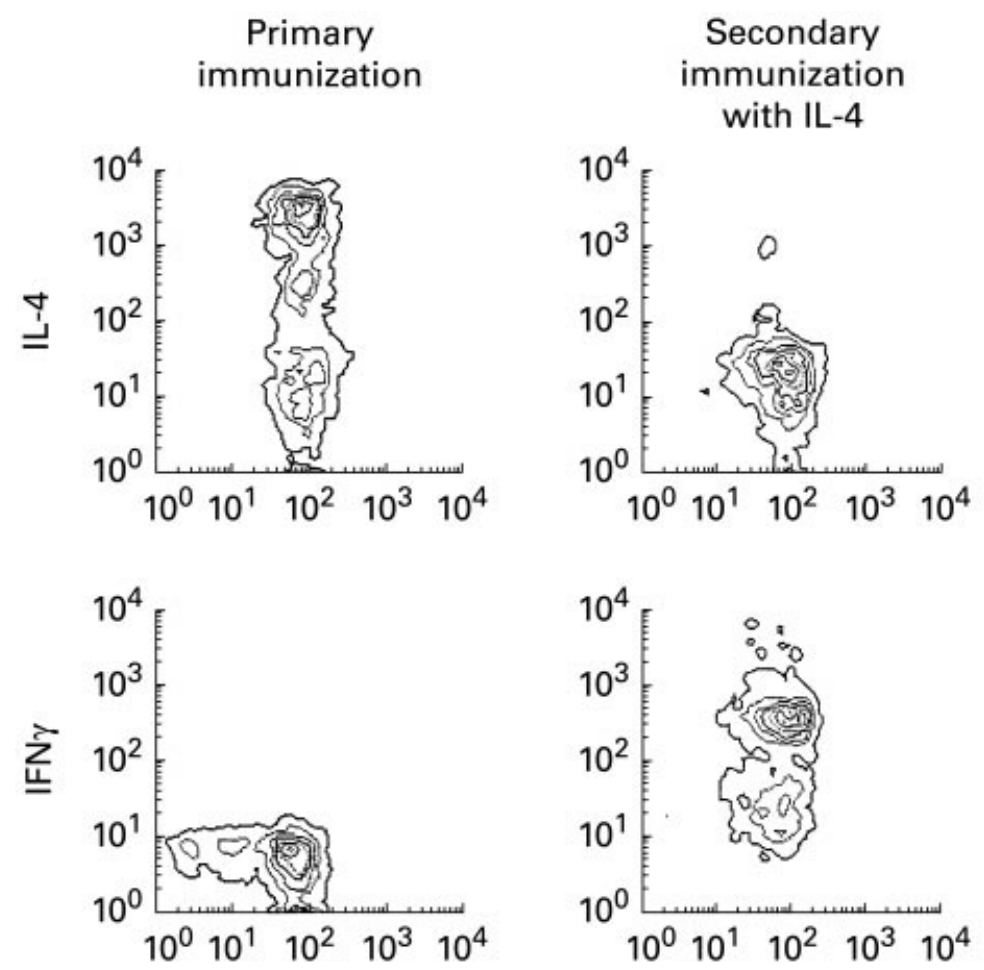

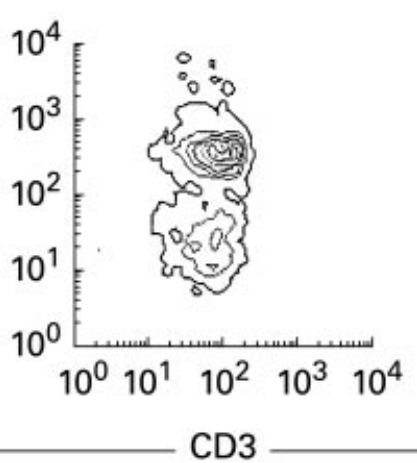

\section{Secondary immunization with IL-4}
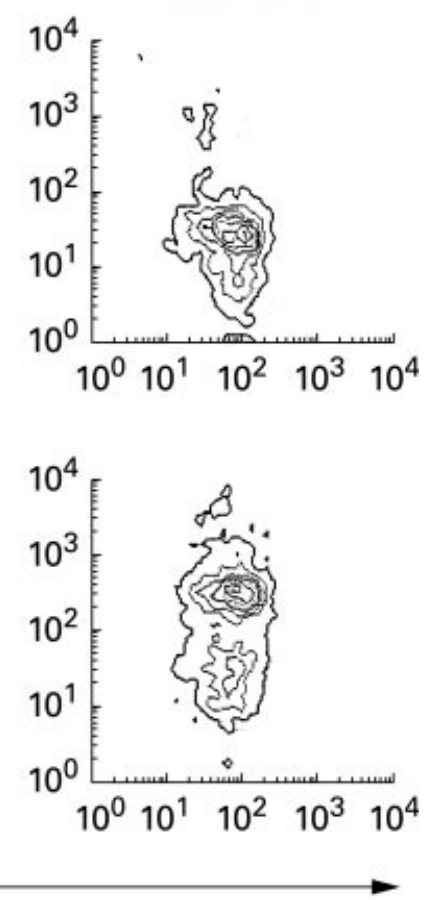

Fig. 2. Cytokine synthesis of $\mathrm{T}$ cells during primary and secondary immunization. Cells were removed from cultures after primary and secondary immunization, and stained for CD3 expression. After fixation and permeabilization the cells were incubated with anti-IL-4 and anti-IFN $\gamma$ antibodies and the presence of intracellular cytokines was determined by FACS analysis.

Interestingly, this activation was characterized by increased levels of one specific DNA-protein complex of highest electrophoretic mobility, indicating the ability of IL-4 to differentially induce one of the DNA-protein complexes (Fig. 3). Similarly, nuclear extracts from primary immunized naive B cells showed high levels of activated $\mathrm{NF}_{\kappa} \mathrm{B}$, where the normal presence of several DNA-protein complexes are evident (Fig. 3). The levels were again independent of IL-4 during the primary immunization period. However, the levels of $\mathrm{NF}_{\kappa} \mathrm{B}$ in nuclear extracts from $\mathrm{B}$ cells following secondary immunization were highly dependent on IL-4. The presence of IL-4 during secondary immunization induced $\mathrm{B}$ cells with significantly higher levels of $\mathrm{NF} \kappa \mathrm{B}$, relative to cells derived from an immunization protocol where IL-4 was absent. This lends further support to the observation of increased frequency of B cell clones secreting IgE in the presence of IL-4 (Table 2).

\section{Discussion}

The induction of IgE in human B cells is mediated by a cognate interaction with $\mathrm{Th} 2$ helper cells. These $\mathrm{T}$ cells deliver signals by ligating the CD40 molecule on B cells and by secreting IL-4, the latter being a crucial signal for isotype switching to IgE [9]. Other signals that have been implicated to play a role in the regulation of IgE production are, e.g. CD21/CD23 interaction, IFN $\gamma$, LFA-1/ICAM-1 interaction, as well as the nature of the antigen itself [18-21]. The mechanisms behind isotype switching and $\operatorname{IgE}$ secretion have been extensively studied, although the focus predominantly has been on total IgE secretion and very little data exists on antigen-specific IgE induction. In particularly, dissection of this response in vitro needs to be performed, since any differential mechanisms behind antigen and allergen could be elucidated in a more controlled environment. It was, e.g. recently demonstrated that CD2 stimulated $\mathrm{T}$ cells together with CD40 and allergen stimulated B cells induce specific IgE production in an IL-4 dependent manner [22]. This specific IgE production was dependent on a low dose of allergen and optimal T-cell stimulation, indicating a delicate control of specific IgE synthesis. The in vitro system used in the present investigation is based on antigen activation of both $\mathrm{T}$ and $\mathrm{B}$ cells, using a recall antigenic epitope for $\mathrm{T}$-cell activation, and has previously been shown to induce antigen-specific isotype switch from $\mu$ to $\gamma[5,12,13]$. The earlier studies focused on 


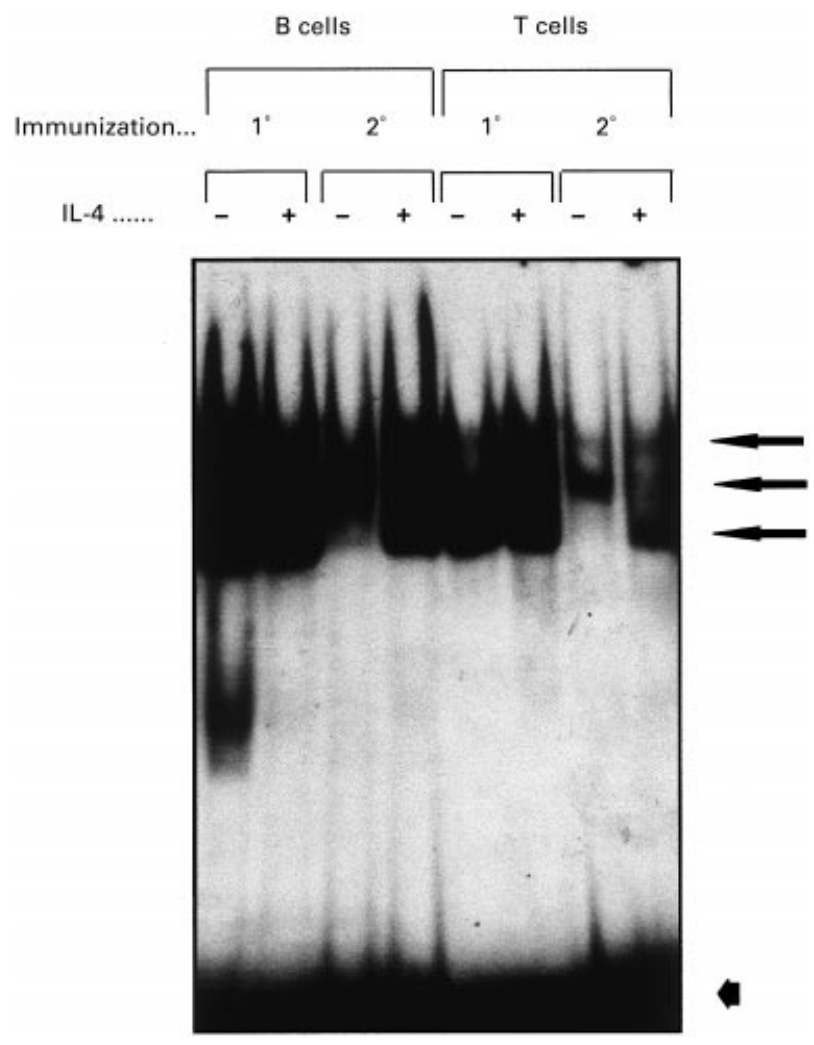

Fig. 3. $N_{F} B$ activation is dependent on additional IL- 4 during secondary but not in primary immunized cultures. B and $\mathrm{T}$ cells from in vitro immunized cultures were separated, nuclear extracts prepared and examined for $\mathrm{NF}_{\kappa} \mathrm{B}$ binding activity, as described in Materials and Methods. Arrows represent at least three different DNA-protein complexes of $\mathrm{NF}_{\kappa} \mathrm{B}$ bound to DNA and the arrow head at the bottom of the figure shows unbound oligonucleotide.

dissecting the signalling mechanism required for isotype switching from $\mu$ to $\gamma$, whereas in the present investigation we have studied the T-cell phenotype, transcription factor activation and effect of cytokines known to affect isotype switching to $\epsilon$. In this study, we could detect antigenspecific IgE antibodies after both primary and secondary immunization periods, where the frequency of B cells producing specific IgE varied between individual donors, as also was observed previously [5]. This indicates that the cells can undergo immunoglobulin class switching within 7 days of culture, since the presence of preswitched IgE + B-cells specific for the V3-peptide in seronegative donors is unlikely. Interestingly, we see after the secondary immunization period (day 8-11) that the ratio of $\mathrm{B}$ cells secreting antigen-specific IgE compared to total IgE increased, indicating an antigen-driven IgE induction. The RI values for the specific IgE antibody responses were generally very strong with clones showing RI $>50$, which is considerably higher compared with RI-index for antigen-specific $\mathrm{IgG}$ antibodies induced by in vitro immunization, as previously reported $[5,12]$.

Furthermore, the frequency of B-cell clones secreting detectable levels of antigen-specific $\operatorname{IgE}$ was $>10$ times higher when soluble IL-4 was present during the secondary culture period. Exogeneously added IL-4 also substantially increased the intracellular levels of $\mathrm{NF} \kappa \mathrm{B}$, which is known to be directly involved in the transcription of $\epsilon$ isotypes. The reason that the secondary stimulation period required addition of IL-4 to support any significant antigen-specific IgE secretion was most probably due to the rapid T-helper cell polarization from Th2 to Th1 that was observed. This is also supported by the fact that the level of IgE synthesis is proportional to the number of Th2 cells added to B cells and the help of Th1 cells is limited by their cytolytic capacity [23].

The phenotype of the T-helper cells was monitored during the culture period, since the subtype of helper cell is crucial to the induction of a humoral immune response in vitro. We found that after the primary immunization the majority of the T cells were of a Th2 phenotype but after an additional 4 day culture period, together with antigenstimulated Th2 cells and anti-CD40 antibodies, the Th cells exhibited a rapid polarization and initiated a secretion of IFN $\gamma$, a Th1 cytokine. Addition of exogenous IL-4 during the secondary immunization could not reverse this differentiation towards a Th1 phenotype. It is also well established that IL-12 induces IFN $\gamma$ production in $\mathrm{T}$ cells and promotes a Th1 cytokine profile [24]. Therefore, we added a blocking anti-IL-12 antibody to the secondary culture in an attempt to prevent the rapid Th1 polarization. Also CD40 signalling of B cells has been shown to induce IL-12 production in human B cells. Addition of anti-IL-12 antibodies as well as removing the anti-CD40 antibodies and the fibroblasts from the secondary cultures failed to prevent the Th2 to Th1 polarization. One possible explanation, presently under investigation, is that the 'default mode' of T-helper cells is Th1, which is indicated by the rapid in vitro polarization. The immune deviation we see in our culture system is similar in concept to what Holt and Macaubas discussed for the in vivo situation in a recent review [25]. They suggested that during infancy, low levels of environmental allergens pass the placenta barrier and together with Th1 inhibitory factors generate T-helper cells skewed towards Th2. An immune deviation after birth will then result in a Th1-skewed memory. It was also recently demonstrated that the Th2-skewed response to common environmental allergens was present in all new born infants suggesting that the key aetiological factor in atopic disease may not be the initial allergenspecific Th2-skewed immunity but rather the efficiency of the underlying mechanisms responsible for the immune deviation [26]. 
When $\mathrm{NF}_{\kappa} \mathrm{B}$ activation was analysed in both $\mathrm{T}$ and $\mathrm{B}$ cells it was clear that $\mathrm{NF} \kappa \mathrm{B}$ was present in the cells during the primary immunization and addition of IL-4 to those cultures did not seem to enhance the expression. In contrast, addition of IL-4-promoted enhanced $\mathrm{NF} \kappa \mathrm{B}$ activation in both $\mathrm{B}$ and $\mathrm{T}$ cells during the secondary immunization. These observations were also supported by Iciek and coworkers [7] who showed that CD40 cross-linking induced $\epsilon$ transcripts via activation of $\mathrm{NF}_{\kappa} \mathrm{B}$ in synergy with IL-4. Thus it seems as if the $\mathrm{T}$ cells in the present assay, during primary immunization, have the proper phenotype to provide B cells with sufficient CD40 stimulation and cytokines to activate $\mathrm{NF} \kappa \mathrm{B}$, which then promotes IgE switching. However, the $\mathrm{T}$ cells rapidly acquired a Th1 phenotype during secondary immunization, which results in the lack of $\mathrm{NF}_{\kappa} \mathrm{B}$ in $\mathrm{B}$ and $\mathrm{T}$ cells during the secondary immunization in cultures not supplemented with IL-4.

In summary, we show that the Th1/Th2 ratio play a fundamental role in the regulation of antigen-specific IgE synthesis in vitro. Furthermore, the data indicate an antigendriven stimulation of the specific B cells, where the specific $\mathrm{IgE}$ secretion was increased by IL-4. In vitro studies might thus play a role when dissecting mechanisms underlying antigen-specific IgE induction and immune deviation.

\section{Acknowledgements}

This investigation was supported by grants from the European Commission (BIO4-CT96-0246) and Vårdalstiftelsen.

\section{References}

1 Romagnani S, Del Prete G, Maggi E, Chilosi M, CaligarisCappio F, Pizzolo G. CD30 and type $2 \mathrm{~T}$ helper (Th2) responses. J Leukocyte Biology 1995; 57:726-30.

2 Mosmann TR, Coffman RL. TH1 and TH2 cells: different patterns of lymphokine secretion lead to different functional properties. Ann Rev Immunol 1989; 7:145-73.

3 Romagnani S. Lymphokine production by human $\mathrm{T}$ cells in disease state. Ann Rev Immunol 1994; 12:227-57.

4 Prescott SL, Macaubas C, Smallacombe T, Holt BJ, Sly PD, Holt PG. Title? Lancet 1999; 353:196-200.

5 Chin LT, Malmborg A-C, Kristensson K, et al. Mimicking the humoral immune response in vitro results in antigen specific isotype switching supported by specific autologous T-helper cells: generation of human HIV-1 neutralizing IgG monoclonal antibodies from naive donors. Eur $\mathrm{J}$ Immunol 1995; 25:657-63.

6 Korthauer U, Graf D, Mages H, et al. Defective expression of T-cell CD40 ligand causes X-linked immunodeficiency with hyper-IgM. Nature 1993; 361:539-54.

$7 \mathrm{Xu} \mathrm{J}$, Foy T, Laman J, et al. Mice deficient for the CD40 ligand. Immunity 1994; 1:423-31.
8 Kawabe T, Naka T, Yoshida K, et al. The immune response in CD40-deficient mice: impared immunoglobulin class switching and germinal center formation. Immunity 1994; 1:169-78.

9 Iciek L, Delphin S, Stavnezer J. CD40 cross-linking induces Ig epsilon germline transcripts in B cells via activation of NF-kappaB: synergy with IL-4 induction. J Immunol 1997; 158:4769-79.

10 Snapper C, Zelazowski P, Rosas F, et al. B cells from p50/NFkappa B knockout mice have selective defects in proliferation, differentiation, germ-line $\mathrm{CH}$ transcription and Ig class switching. J Immunol 1996; 156:183-91.

11 Ullman KS, Northrop JP, Verweij CL, Crabtree GR. Transmission of signals from the $\mathrm{T}$ lymphocyte antigen receptor to the genes responsible for cell proliferation and immune function: the missing link. Ann Rev Immunol 1990; 8:421-52.

12 Zafiropoulos A, Andersson E, Krambovitis E, Borrebaeck CAK. Induction of antigen-specific isotype switching by in vitro immunization of human naive B lymphocytes. J Immunol Methods 1997; 15:181-90.

13 Chin LT, Hinkula JM, Ohlin M, Wahren B, Borrebaeck CAK. Site-directed primary in vitro immunizaton: production of HIV-1 neutralising human monoclonal antibodies from lymphocytes obtained form seronegative donors. Immunology 1994; 81:428-34.

14 Ohlin M, Borrebaeck CAK. In: Masseyeff RF, Albert WHW \& Staines N. eds. 1993 Methods of Immunological Analysis, VCH Verlagsgesellschaft mbH, Weinheim, Germany, p298.

15 Annunziato F, Manetti R, Cosmi L, et al. Opposite role for interleukin- 4 and interferon- $\gamma$ on CD30 and lymphocyte activation gene-3 (LAG-3) expression by activated naive T cells. Eur J Immunol 1997; 27:2239-44.

16 Bradford MM. A rapid and sensitive method for the quantification of microgram quantities of protein utilizing the principle of protein-dye binding. Anal Biochem 1976; 72:248-54.

17 Sambrook J, Fritsch EF, Maniatis T. Molecular Cloning: a Laboratory Manual Cold Spring Harbor Laboratory Press, Cold Spring Harbor, 1989, pp 568-71.

18 Bonnefoy JY, Gauchat JF, Life P, et al. Pairs of surface molecules involved in human IgE regulation CD23-CD21 CD40-CD40L. Eur Respir J 1996; 22:63-6.

19 Ohmori H, Hikida M, Haruna K, Kishimoto T. In vitro antigenspecific $\mathrm{IgE}$ response is refractory to suppression by interferongamma. Immunol Lett 1992; 34:99-104.

20 Tanaka Y, Takahashi A, Arai I, et al. Prolonged inhibition of an antigen-specific IgE response in vivo by monoclonal antibody against lymphocyte function-associated antigen-1. Eur $\mathrm{J}$ Immunol 1995; 25:1555-8.

21 Blaser K. Allergen dose dependent cytokine production regulates specific IgE and IgG antibody production. Adv Exp Med Biol 1996; 409:295-303.

22 Akdis CA, Blesken T, Akdis M, et al. Induction and differential regulation of bee venom phospholipase A2-specific human IgE and IgG4 antibodies in vitro requires allergen-specific and nonspecific activation of T and B cells. J Allergy Clin Immunol 1997; 99:345-53.

23 Del Prete GF, De Carli M, Ricci M, Romagnani S. Helper activity for immunoglobulin synthesis of T helper 1 (Th1) and 
Th2 human T cell clones: the help of Th1 clones is limited by their cytolytic capacity. J Exp Med 1991; 174:809-13.

24 Nakamura T, Kamogawa Y, Bottomly K, Flavell RA. Polarization of IL- 4 and IFN- $\gamma$-producing $\mathrm{CD}^{+}{ }^{+}$cells following activation of naive CD4 ${ }^{+} \mathrm{T}$ cells. J Immunol 1997; 158:108594.

25 Holt PG, Macaubas C. Development of long term tolerance versus sensitisation to environmental allergens during perinatal period. Curr Opinion Immunol 1997; 9:782-7.

26 Prescott SL, Macaubas C, Holt BJ, et al. Transplacental priming of the human immune system to environmental allergens: Universal skewing of initial $\mathrm{T}$ cell responses towards the Th2 cytokine profile. J Immunol 1998; 160: 4730-7. 
This document is a scanned copy of a printed document. No warranty is given about the accuracy of the copy. Users should refer to the original published version of the material. 